\title{
ANTAgonism AND MOdes OF ACTION OF CHAETOMIUM GLOBOSUM SPECIES GROUP, POTENTIAL BIOCONTROL AGENT OF BARLEY FOLIAR DISEASES
}

\author{
PAULINA MOYA ${ }^{1,3^{*}}$, DEBORA PEDEMONTE ${ }^{1}$, SUSANA AMENGUAL ${ }^{1}$, MARIO E. E. \\ FRANCO ${ }^{1,4}$, MARINA N. SISTERNA ${ }^{1,2}$
}

\begin{abstract}
Resumen: Antagonismo y mecanismos de acción de hongos del grupo de especies Chaetomium globosum, potenciales biocontroladores de enfermedades fúngicas foliares de la cebada. La "mancha en red y la "mancha borrosa" son enfermedades foliares de cebada causadas por Drechslera teres y Bipolaris sorokiniana, respectivamente. Una alternativa para su manejo es el control biológico. El objetivo de este trabajo fue identificar dos aislamientos del género Chaetomium (C2 y C5), endofíticos de plántulas de cebada y estudiar sus interacciónes in vitro con $D$. teres y $B$. sorokiniana, aisladas de semillas del mismo hospedante. Todos los microorganismos se caracterizaron cultural y morfológicamente. Los aislamientos de Chaetomium además se caracterizaron molecularmente. Se realizaron pruebas de cultivos duales y se registraron los efectos del antagonista a nivel microscópico en la morfología de los patógenos. Los resultados confirmaron la identidad de los patógenos y de los aislamientos de Chaetomium spp. como Chaetomium globosum grupo de especies. Bipolaris sorokiniana fue inhibida en un $30 \%$ por $\mathrm{C} 2$ y en un $31.2 \%$ por C5 respecto al control. D.teres fue inhibida en un $40 \%$ por C2 y en un 36\% por C5 en referencia al control. Los mecanismos de acción frente a $B$. sorokiniana fueron antibiosis y competencia. Microscopicamente se observaron conidios aberrantes. Frente a $D$. teres se registró competencia y micoparasitismo. Microscópicamente se evidenció plasmólisis, enrollamiento y pigmentación anaranjada.
\end{abstract}

Palabras clave: Bipolaris sorokiniana, Chaetomium globosum, Drechslera teres, antibiosis, endófito, micoparasitismo.

Summary: "Net blotch" (Drechslera teres) and "Bipolaris spot blotch" (Bipolaris sorokiniana) are foliar diseases of barley. Biological control is currently considered as an efficient alternative to chemical management of these plant diseases. The aim of the present study was to identify 2 isolates of Chaetomium (C2 and C5), endophytics on barley seedlings and to study the in vitro interactions with $D$. teres and $B$. sorokiniana, isolated from seeds of the same host. Cultural and morphological characterization of all microorganisms was done. In addition, molecular characterization of Chaetomium spp. was conducted and dual culture tests were carried out to find, by microscopic observations, the effects of the antagonist on the morphology of the pathogens. The results confirm the identity of the pathogens and the isolates of Chaetomium spp. as Chaetomium globosum species group. Inhibition of $B$. sorokiniana and $D$. teres by $\mathrm{C} 2$ and $\mathrm{C} 5$ accounted for $30 \%$ and $31.2 \%$, and $40 \%$ and $36 \%$ respectively, compared with the control. The mechanisms of action against $B$. sorokiniana and $D$. teres were antibiosis and competition and mycoparasitism, respectively. Microscopic observation revealed deformed conidia in $B$. sorokiniana and plasmolisis, coiling and orange pigmentation in D. teres.

Key words: Bipolaris sorokiniana, Chaetomium globosum, Drechslera teres, antibiosis, endophyte, mycoparasitism.

\footnotetext{
${ }^{1}$ Centro de Investigaciones de Fitopatología (CIDEFI) - Facultad de Ciencias Agrarias y Forestales, Universidad Nacional de La Plata. 60 y 119, (1900) La Plata, Buenos Aires, Argentina.

${ }^{2}$ Comisión de Investigaciones Científicas de la Provincia de Buenos Aires (CICPBA)

${ }^{3}$ Consejo Nacional de Investigaciones Científicas y Técnicas (CONICET).

${ }^{4}$ Agencia Nacional de Promoción Científica y Tecnológica

Autor para correspondencia : p_moya_@hotmail.com
} 


\section{INTRODUCTION}

Malting barley crop (Hordeum distichum L.) plays a key role in the cereal global production. In Argentina, malting barley production covers an area of approximately 1.000 .000 hectares (MAGyP, 2014). As a result of minimum tillage and the use of susceptible cultivars, diseases have become an increasing problem (Carmona 2009)."Net blotch" (Drechslera teres (Sacc.) Shoem. (teleomorph Pyrenophora teres Drechsler), is an endemic disease, it means that remains in a particular area, with a prevalence of $76 \%$ and an incidence of $100 \%$, being responsible for yield losses of 20\% (Carmona et al., 1999). The most affected components include grain weight and the number of grains per square meter. Also, the malt extract decreases, affecting malt quality for beer production (Carmona 2009). "Bipolaris spot blotch" (Bipolaris sorokiniana) (Sacc.) Shoemaker causes foliar lesions and this pathogen also affects other plant parts producing discoloration grain, seedling blight and root rot (Fernández Valiela, 1978; Wiese, 1987). In Argentina, frequency and incidence of Bipolaris spot blotch has increased in regions with more moderate temperatures. In addition, the barley growing region extends to the central-north provinces (Santa Fe, Entre Ríos) resulting in a highest risk of disease spread due to the fact that temperate humid regions are the most favorable areas for the disease occurrence (Carmona, 2009). All these causes have established Bipolaris spot blotch as a re-emerging disease (Sisterna, 2014).

Biocontrol is an environmental-friendly and efficient alternative to chemical pesticide management of plant diseases. In this sense, endophyte organisms, particularly fungi, have received major attention in recent years. Endophytes are capable to reduce in the host the effect of fungi deseases, through secondary metabolites production as alkaloids (Abello \& Kelemu 2006). The plantendophyte relationship is so strong that could be involved in the systemic induced resistance (Waller et al., 2005). All these mechanisms lead to a higher competitive ability compared to plant endophyte free (Vila-Aiub et al., 2003).

There are many studies with promising results on using endophyte Chaetomium spp. as a biocontrol agent. Antagonistic mechanisms of this fungus include competition for space and nutrients (Vannaci
\& Harman 1987), mycoparasitism (Mandal et al., 1999) and metabolite production (antibiosis) such as chaetomin, chaetoglobosin, cochliodinol, chaetosin and prenisatin (Brewer et al., 1970; Brewer et al., 1972; Brewer \& Taylor, 1978). Other microscopic studies analyzed deformed conidia with distorted walls, lisis and formation of holes in the host pathogen mycelium, inhibition in conidial germination and hyphal elongation (Mandal et al., 1999; Biswas et al., 2000).

Chaetomium spp. is reported as antagonist of soil and foliar pathogens (Soytong et al., 2001) in rice (Soytong, 1992), maize (Soytong, 1991) and wheat (Biswas et al., 2000; Aggarwal et al., 2004; Istifadah \& McGee, 2006; Istifadah et al., 2006).

The aim of the present study was to analyze in vitro interactions between two isolates of Chaetomium globosum species group, previously morphocultural and molecular characterized, with Bipolaris sorokiniana and Drechslera teres, fungi phytopathogens of barley.

\section{Materials and Methods}

\section{Isolation of microorganisms}

Drechslera teres and B. sorokiniana were isolated from samples of naturally infected barley seeds from cv. Scarlet, cultivated in Tres Arroyos locality (Buenos Aires Province). The agar method was used following the rules imparted by ISTA (Neegaard, 1979). On the other hand, 12 isolates of Chaetomium spp. were obtained from previous biocontrol greenhouse tests. In them, from barley seedlings, small pieces of leaves were disinfected in $70 \%$ ethanol $\left(1 \frac{1 / 2}{\mathrm{~min}}\right), 5 \%$ sodium hypoclorite $\left(1 \frac{1}{2} \mathrm{~min}\right)$, rinsed in sterile destilled water $(3 \mathrm{~min})$ and placed in Petri dishes with potato dextrose agar (PDA) medium $2 \%$. The dishes were incubated for 5-6 days at $25^{\circ} \mathrm{C}$, until colony growth was observed. Pure cultures used in subsequent studies were stored on slants of PDA.

Cultural and morphological characterization of isolates of Chaetomium spp. Drechslera teres and Bipolaris sorokiniana

Among the 12 Chaetomium isolates, two groups with cultural and morphological differences were a priori distinguished. From them, one isolate from each one (C2 and $\mathrm{C} 5)$ were chosen as 
representatives.

Vegetative and reproductive structures of both isolates were studied. Also their cultural characteristics were analyzed on different media: potato - dextrose agar (PDA), oatmeal agar (OA) and malt extract agar (MEA). The isolates were grown in darkness at temperature $23^{\circ}$ and five replications from each treatment were done. The parameters evaluated at 7,14 and 21 days were: average diameter and colour (according to Rayner 1970).

Ascomatas descriptions and spores microscopic measurements were taken from colonies grown on OA. This was the medium where the isolates gave the best sporulation. Domsch et al. (2007) keys were followed to the systematic classification. Other specific literature (Dreyfuss et al.,1986; Ames 1963; Von Arx et al., 1986) were consulted for the morfo-cultural characterization.

Drechslera teres and B. sorokiniana were characterized based on cultural and morphological characteristics, following routine phytopathologic methods and specific literature (Ellis, 1971, 1976; Sivanesan, 1987)

\section{Molecular characterization of Chaetomium isolates}

From the monosporic cultures of the two isolates of Chaetomium spp. C2 and C5, DNA was isolated using the CTAB method of Doyle \& Doyle (1990), modified by Bornet and Branchard (2001). Amplification was performed using ribosomal DNA fragment that conforms the ITS (Internal Transcribed Spacer ITS1 - ITS4), with primers ITS 1 (5'-TCCGTAGGTGAACCTGCGG-3') and ITS4 (5'-TCCTCCGCTTATTGATATGC-3') (White et al., 1990). The amplification reaction was performed under the following conditions: one cycle of initial denaturation at $94{ }^{\circ} \mathrm{C}$ for 4 minutes; 33 cycles at $94{ }^{\circ} \mathrm{C}$ for 1 minute, 45 seconds at 56 ${ }^{\circ} \mathrm{C}$ and at 72 minutes and finally an elongation of 5 minutes at $72{ }^{\circ} \mathrm{C}$ (Curtis et al., 1994; Goodwin et al., 2001). The reaction mixture consisted of $1 \mathrm{X}$ reaction buffer $(500 \mathrm{mM} \mathrm{KCl} ; 100 \mathrm{mM}$ Tris- $\mathrm{HCl}$, pH 9.0 at 25; 1\% Triton X-100 (no magnesium)); $1.5 \mathrm{mM}$ magnesium chloride; $0.2 \mathrm{mM}$ of each dNTP; $0.3 \mathrm{mM}$ of each primer; $1 \mathrm{U}$ of T-Plus DNA polymerase (Molecular Biology-Highway INBIO-UNICEN) and $50 \mathrm{ng}$ of template DNA per reaction, in a final volume of $15 \mathrm{ul}$. The amplified fragments were purified by adding one volume of isopropanol and 0.1 volume of $3 \mathrm{M}$ Sodium Acetate. The mixture was kept at $-18^{\circ} \mathrm{C}$ for 12 hours and then centrifuged at $15,000 \mathrm{~g}$ for 15 minutes. The DNA was washed with $70 \%$ ethanol, then dried and dissolved in sterile distilled water (Maniatis et.al., 1982). The two strands of the DNA fragment amplified by PCR were sequenced in Macrogen Inc. Seoul, Korea. The sequences were deposited in databases DDBJ / EMBL / GenBank under the access numbers KX011856 for isolate $\mathrm{C} 2$ and KX011855 for isolate C5.

\section{In vitro antagonistic test}

The inhibitory action of $\mathrm{C} 2$ and $\mathrm{C} 5$ against the two pathogens was tested in dual culture (Dal Bello et al., 1994). An antagonist disc (5 mm. diameter) was placed in the Petri dish containing $9 \mathrm{ml}$. PDA. After three days, a pathogen disc was placed leaving $4 \mathrm{~cm}$. distance from the first disc. Three replicates of each pathogen-antagonist interaction were done. A culture of each pathogen alone served as control. The Petri dishes with the dual cultures were incubated for 7 days at $25^{\circ} \mathrm{C}$. Two diameters perpendicular to each pathogenic colony were measured for all treatments and average values were determined. These values were analyzed by the Kruscal Wallis test and then Tukey test was conducted to find the differences among treatments.

To reveal the effects of the antagonist on the pathogen morphology, microscopic observations were performed.

\section{Results}

Cultural and morphological characterization of isolates of Chaetomium spp., D. teres and B. sorokiniana

In $\mathrm{OA}$ the isolates showed olivaceous-yellow colonies according to the color of (Rayner, 1970). Isolate $\mathrm{C} 5$ showed globose or oval ostiolar ascomata with straight or undulate hairs (Fig. 1A) unlike isolate 2, which showed irregular hairs with no undulations (Fig. 1B). Both isolates showed terminal hairs all unbranched and displayed one-celled, lemon-shaped ascospores, with an apical germ pore and regular in shape with sizes: $\mathrm{C} 2: 8.4 \mu \mathrm{m} \times 6 \mu \mathrm{m}$; C5: $9.6 \mu \mathrm{m} \times 7.68 \mu \mathrm{m}$ (Fig. 1C). In PDA isolate C5 was slightly yellower than $\mathrm{C} 2$ and showed margins wavy or irregular, while C2 developed full edges. In 
MEA both isolates were transparent. The growth on the several media did not evidence major differences. It was slightly higher on OA, followed by APG and MEA. At 7 days, on the three media, $\mathrm{C} 2$ grew faster than $\mathrm{C} 5$. Then the growth stabilized. The morphocultural characteristics of $\mathrm{C} 2$ and $\mathrm{C} 5$ isolates were very close to $C$. globosum.

The isolates of $B$. sorokiniana showed grey olivaceous to black velvet-like colonies with wavy or irregular margins, abundantly sporulating (Fig. 1D). B. sorokiniana displayed curved conidia, though in culture they are frequently straight, fusoid or elipsoid, dark brown in color, smooth, 4 to 12 pseudosepta, 40-120 (80) x 17-28(22.5) $\mu \mathrm{m}$. (Figure 1E).

D. teres showed typical cultural characteristics of the species. The mycelium was initially medium grey (Rayner, 1970) with white tuft-like formations (Fig. 1F) near the edge of the colony. The conidia were straight, cylindrical, rounded at the ends, subhyaline, yellowish brown to olivaceous brown, 4 to 6 pseudosepta, 72-105 (88.5) x 12-21 (14.4) $\mu \mathrm{m}$ L/A (Fig. 1G).

\section{Molecular identification of Chaetomium isolates}

ITS amplicons for strains C2 and C5 had sizes of 557 and 556 bp. respectively. A search of both sequences in the GenBank database using BLAST tool found that the sequence KX011855 was 99\% identical to its counterpart Chaetomium globosum strain CGMCC of 3.14295 (JN209864.1), isolated in China, while KX011856 what the sequence was $100 \%$ for Chaetomium globosum voucher CIAT563 (KR012922.1) of Colombian origin. However, it also were found high levels of sequence identity with other species of the same genus so this controversial result made the identification impossible only based on the nucleotide sequence of the ITS.

\section{In vitro culture test}

The results of the C.globosum - B. sorokiniana interaction were showed in Table 1.

Seven days after incubation significant differences were observed among treatments (K: $23.49 \mathrm{p}=$ $0.000008)$. According to the Tukey test strains C2 and C5 did not show significant differences in their inhibitory capacity between them. However,

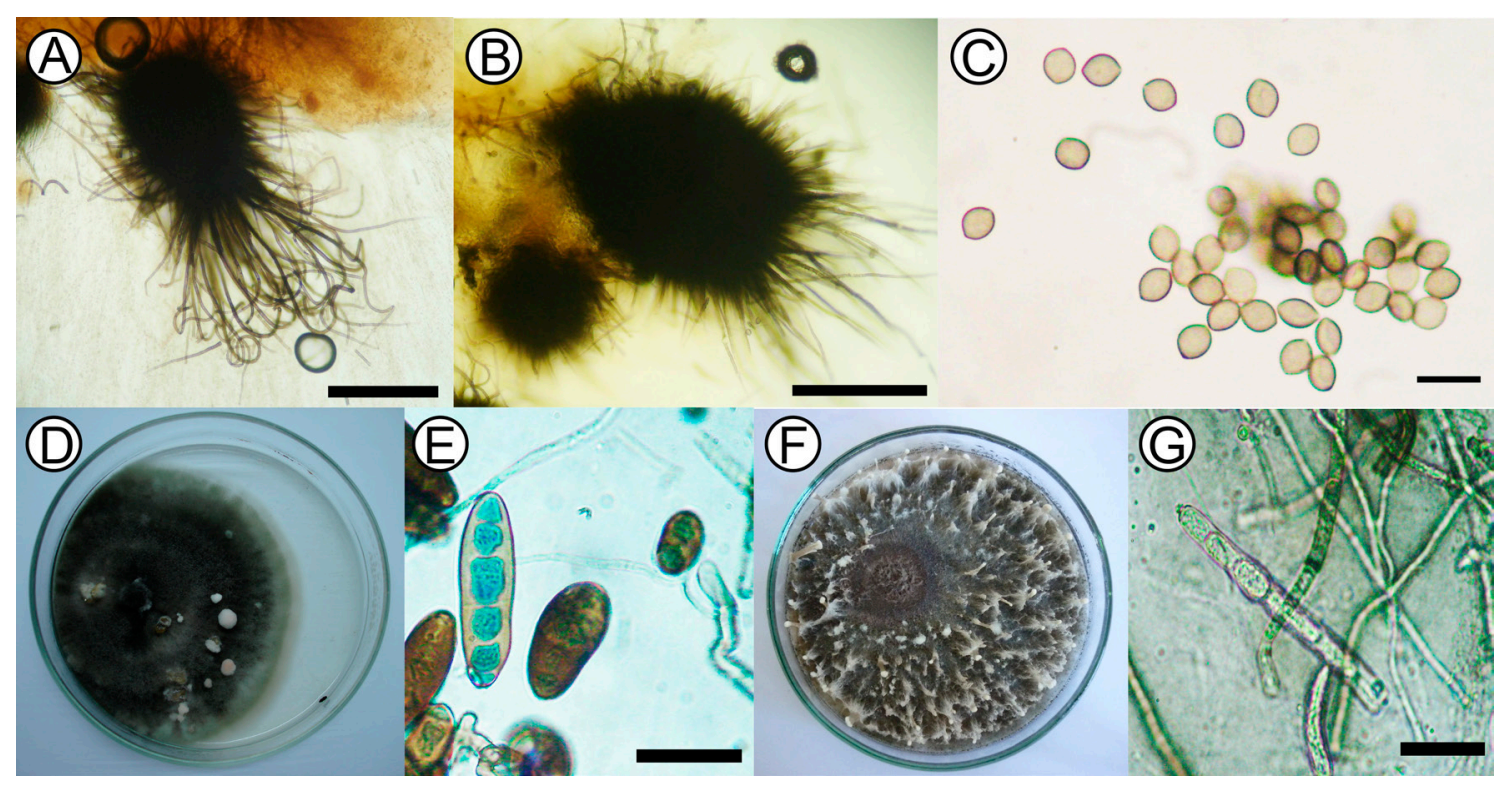

Fig. 1. Monoespecific cultures: (A) Ascomata from Chaetomium globosum strain 5, globose or oval ostiolar with straight or undulate hairs. OM 40X scar $=200 \mu \mathrm{m}$. (B) Ascomata from Chaetomium globosum strain 2, with irregular hairs without undulations. OM 40X scar $=200 \mu \mathrm{m}$. (C) Unicellular, lemon-shaped ascospores of $C$. globosum strain 2; OM 40X scar $=10 \mu \mathrm{m}$. (D) Colonies of Bipolaris sorokiniana and (E) conidia. OM 40X scar $=50 \mu \mathrm{m}$. (F) Mycelium of Drechslera teres with white tuft-like formations. (G) Cylindrical and rounded ends conidia of $D$. teres OM $40 \mathrm{X}$ scar $=50 \mu \mathrm{m}$. 
Table 1. Average values of the mycelial growth of Bipolaris sorokiniana in the presence of $C$. globosum C2, C5 and controls. Within the average column, means followed by the same letter are not significantly different $(\mathrm{P}<0.001)$ by the Tukey test.

\begin{tabular}{|lccc|}
\hline \multicolumn{1}{|c}{ Treatments } & $\mathbf{N}$ & Average & S.E. \\
\hline Control & 12 & $7.15 \mathrm{~b}$ & \pm 0.04 \\
C2 & 12 & $5.02 \mathrm{a}$ & \pm 0.58 \\
C5 & 12 & $4.92 \mathrm{a}$ & \pm 0.34 \\
\hline
\end{tabular}

significant differences were observed with respect to the control. The inhibitory effect of $\mathrm{C} 2$ and $\mathrm{C} 5$ were $30 \%$ and $31 \%$, respectively.

Similar conditions regarding C. globosum - D. teres interaction were observed in Table 2 (K: 23.76 $\mathrm{p}=0.000007)$ with significant differences with respect to the control and no significant differences between the isolates. C2 inhibited 40\% and C5 36\% with respect to the control (Fig. 2).

The predominant mecanism of action of $C$. globosum species group against $B$. sorokiniana was antibiosis (Fig. 3A). Other mechanisms,

Table 2. Average values of the mycelial growth of
Drechslera teres in the presence of $C$. globosum $\mathrm{C} 2$,
C5 and controls. Within the average column, means
followed by the same letter are not significantly
different $(\mathrm{P}<0.001)$ by the Tukey test.
\begin{tabular}{|lccc}
\hline Treatment & N & Average & S.E. \\
Control & 12 & 8.72 b & \pm 0.05 \\
C2 & 12 & 5.29 a & \pm 0.28 \\
C5 & 12 & 5.56 a & \pm 0.12 \\
\hline
\end{tabular}

such as competition were also observed (Fig. 3B). Microscopic observation of B. sorokiniana revealed abnormal conidia as a result of the contact with C. globosum species group. (Fig. $3 \mathrm{C})$.

The most important mechanisms displayed by C. globosum - D. teres included competition and mycoparasitism, with an orange pigmentation in the interaction zone (Fig. 3D y 3E). Microscopic observations of $C$. globosum - D. teres interaction revealed plasmolisis (Fig. 4A), hyphal coiling (Fig. 4B) and orange pigmentation (Fig. 4C).

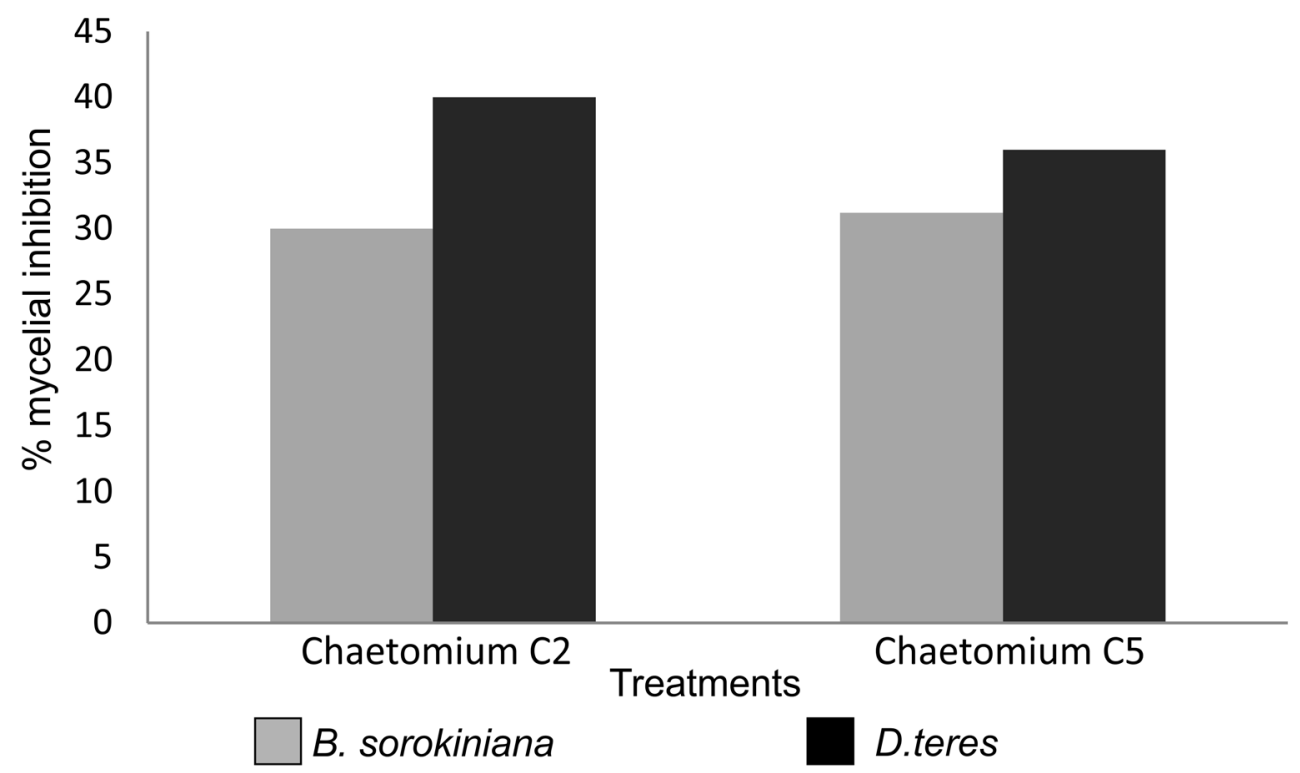

Fig. 2. Percent of mycelial growth inhibition of Bipolaris sorokiniana and Drechslera teres caused by Chaetomium globosum strains $\mathrm{C} 2$ and $\mathrm{C} 5$. 


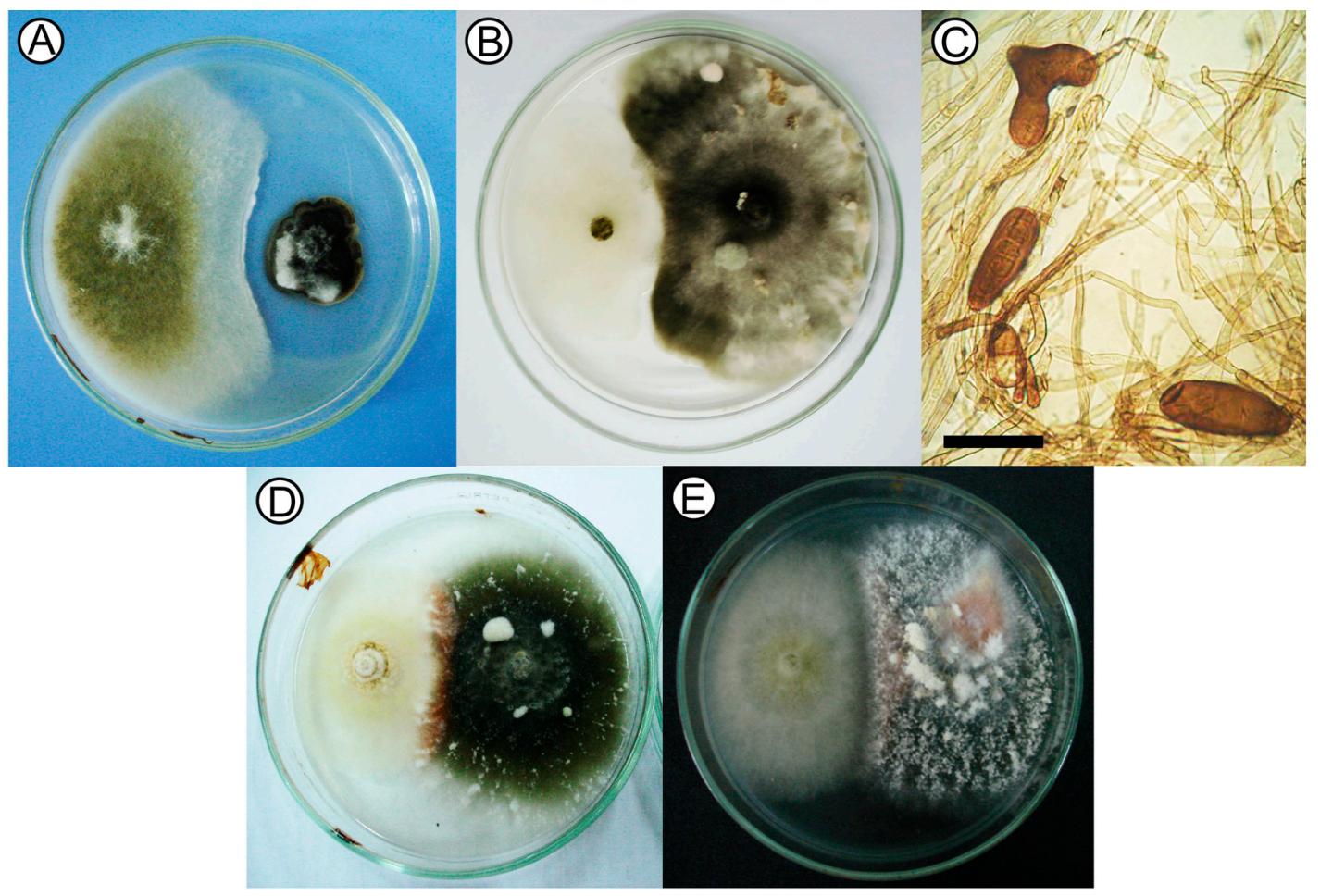

Fig. 3. Antagonistic interactions of dual cultures of C. globosum against B. sorokiniana: (A) Antibiosis; (B) Competition. (C) B. sorokiniana abnormal conidia. OM 40X scar $=50 \mu \mathrm{m}$. (D) Orange pigmentation in the interaction area between $D$. teres- C2 ; (E) D. teres-C5.

\section{Discussion}

Following biocontrol steps, in vitro assays are necessary to carry out a second stage of in vivo assays. This investigation gives a first approach on the knowledge for C. globosum application in vivo, as a biocontrol agent of spot blotch and net blotch. For that, the identification to a specific level is of great importance, as well as its characterization. The study of each species allows deeper knowledge to evaluate antagonistic behavior.

Chaetomium globosum is by far the commonest and most cosmopolitan Chaetomium species especially on plant remains, seeds, compost paper and other cellulosic substrates. (Domsch et al., 2007).

Several authors have tried unsuccessfully to define sections of Chaetomium based on morphological characters, which later proved to be heterogeneous. Ames (1963) distinguished 10 groups based on the shape of ascomatal hairs. Sörgel (1960) suggested a subdivision of Chaetomium into 13 species groups based on ascospore features. Seth (1970) used ascospore shape and ascomatal hairs separately to distinguish eight species groups. A comprehensive classification system of Chaetomium was proposed by Dreyfuss (1976). Based on morphological characters (ascogonia, asci, ascospores and anamorphs) together with some physiological traits (temperature and nutritional requirements, growth and fruiting rate, compatibility, etc.), he divided the genus into four species groups, namely $C$. aureum, $C$. bostrychodes, C. globosum and C. murorum. Von Arx et al. (1986) provided a more comprehensive revision, which largely followed the concepts of Sörgel (1960) and Dreyfuss (1976), recognizing only 134 species.

Cultural and morphological characterization of $\mathrm{C} 2$ and $\mathrm{C} 5$ isolates agrees whith the description 


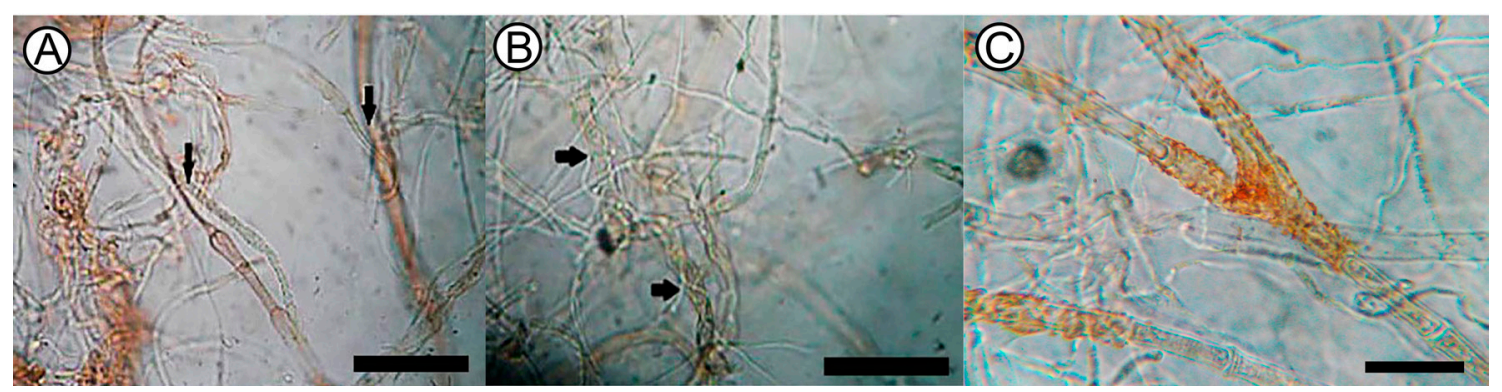

Fig. 4. Chaetomium globosum - Drechslera teres interaction area (A) plasmolisis; (B) hyphal coiling; (C) orange pigmentation. OM 40X scar $=50 \mu \mathrm{m}$.

of Dreyfus et al. (1976) for the Chaetomium globosum species group. Its main characteristics are the presence of limoniform spores and peridials hairs, ranging from wavy to straight. A peridium exclusively of textura intricata or in combinations with textura epidermoidea, ascospores ranging from limoniform with apiculate ends to ellipsoidal or nearly spherical without apiculate ends, and with one (rarely two) germ pores (Asgari \& Zare 2011). In the present study, colour and measurements of colonies, ascospores size and type and shape of peridial hairs agree with that reported by Domsch et al. (2007).

Scarce investigations have been performed on molecular taxonomy. Chaetomium spp.and other members of the Chaetomiaceae were studied with $18 \mathrm{~S}$ and $28 \mathrm{~S}$ rDNA sequences individually (Lee \& Hanlin 1999, Untereiner et al. 2001) or in combination with tef and $\mathrm{rpb} 2$ genes (Zhang et al., 2006). These studies have supported the monophyly of the Chaetomiaceae, occupying a sister relationship to other families of Sordariales, especially Lasiosphaeriaceae.

Asgari \& Zare (2011) analyzed 21 species of Chaetomium taxa, on the basis of morphological and molecular characters, using a combined sequence dataset of the ITS region, partial LSU rDNA, and b-tubulin gene.

In this investigation high levels of $\mathrm{C} 2$ and C5 identity with Gene Bank sequences of $C$. globosum were found but also high levels with other species of the genera. This result difficults the identification, based exclusively in the ITS nucleotidic sequence. Rodríguez Morejón (2003) found similar difficulties. This reasercher used the highly conserved region D1 and D2 from 288 $\mathrm{ADNr}$ and demonstrated that a unique gen cannot be used in the molecular study of C. globosum. To confirm the identity of both isolates through molecular tools it will be necessary to combine sequence dataset of the ITS region, partial LSU rDNA, and b-tubulin (Asgari \& Zare 2011). So we can conclude that, in this study, isolates $\mathrm{C} 2$ and $\mathrm{C} 5$ are clasified inside the C. globosum species group, not being posible to reach to the species level with the sequences analyzed.

The present study reveals that in in vitro dual tests, both Chaetomium isolates, $\mathrm{C} 2$ and $\mathrm{C} 5$, inhibited the two pathogens. Aggarwal et al., (2004), Biswas et al., (2000) and Mandal et al., (1999) found similar results for B.sorokiniana. Also, Tathan et al., (2012) working in vitro with $B$. oryzae demostrated antagonist activity of several species of Chaetomium.

No studies are available for D.teres on this regard. However, Istifadah \& McGee (2006); Istifadah et al. (2006) worked on the interaction between isolates of Chaetomium globosum and D. tritici-repentis, another species of this genus, which is responsible for the wheat tan spot.

The orange pigmentation observed in the interaction area $C$ globosum-D.teres, both at microscopic and macroscopic level was also described in other interactions with $D$. teres and the antagonist Trichoderma spp. (Moya \& Sisterna 2012; Moya et al., 2015). Related studies referred this coloration to the presence of anthraquinones, particularly catenarin. These metabolites could play an antifungal and antibacterial role (Engström et al., 1993; Wakuliński et al,. 2003). 
Antibiosis was the most prevalent mechanism of action between C. globosum-B. sorokiniana in agreement with studies by Aggarwal et al. (2004). Biswas et al. (2000) and Mandal et al. (1999) also observed this mechanism in their experiments. Istifadah et al. (2006) found the same effect against D. tritici-repentis. The role of this mechanism in the antagonist activity of $C$. globosum against Venturia inaequalis, Pythium ultimum, Fusarium nivale, Sclerotinia sclerotiorum and Helminthosporium spp. has also been recorded by several researchers (Tveit \& Wood, 1955; Hubbard et al., 1982; Cullen \& Andrews, 1984; Di Pietro, 1992; Nakashima et al., 1991). Chaetomium spp. produces a diverse amount of bioactive metabolites such as chaetoglobosin A, chaetomin, cochliodinol and prenisatin that inhibit the growth of the pathogens in vitro (Brewer et al., 1972; Breinholt et al., 1996). Other authors suggest that the antibiosis must not be the most important mechanism of action of an antagonist, since there is a risk of occurrence of pathogenic strains resistant to antibiotics (Infante et al., 2009).

Competition constitutes a major antagonistic mechanism, which is favoured by the biocontrol agent characteristics such as ecological plasticity, growth velocity and development and by external factors such as soil type, $\mathrm{pH}$, temperature, humidity, among others (Infante et al., 2009). In the present study, antagonism by competition, with reduction of the growth of the pathogen mycelium was also observed both in B. sorokiniana and D. teres interactions. Few studies on this mechanism of action were found in Chaetomium spp. (Vanacci \& Harman, 1987). Mycoparasitism was observed in the interaction between C.globosum and $B$. sorokiniana. This mode of action produced conidia deformation. Similar results were reported by Biswas et al. (2000). Also, Mandal et al. (1999) observed, between these organisms, hyphal interaction with lisis and perforation of the pathogen wall caused by the antagonist.

In the interaction between C. globosum and $D$. teres, hyphal coiling was observed. The same was found by Vannacci \& Harman (1987) who studied the interaction C. globosum - Alternaria brassicicola and C. globosum - A. raphani and between this antagonist and Rhizoctonia solani. These interactions also revealed intracelular growth of C. globosum in the pathogen hyphae (Gao et al., 2005).
In Argentina, no studies in vitro on the interaction between the endophyte Chaetomium globosum species group and phytopathogenic agents have been reported. Therefore, the present study provides information regarding the relationship between this antagonist and phytopatogenic fungi of barley. Future research should consider the use of this endophyte as a usefull control tool in an integrated strategy for disease treatments.

\section{Acknowledgements}

We want to especially thank Dr. Pedro Balatti from UNLP (Universidad Nacional de La Plata) for their contribution to molecular characterization of Chaetomium spp. This paper was performed with financial support from CONICET (Consejo Nacional de Investigaciones Científicas y Técnicas), CICPBA (Comisión de Investigaciones Científicas de la Provincia de Bs. As.) and UNLP.

\section{BibliogRAPHY}

ABELLO, J. F \& S. KELEMU. 2006. Hongos endófitos: ventajas adaptativas que habitan en el interior de las plantas. Revista CORPOICA 7: 55-57. Disponible en: http://www.corpoica.org.co/SitioWeb/Archivos/ Revista/6_HongosEndfitos_RevCorpoica_ V7N2_2006_CorregidoDEF.pdf

AGGARWALL, R., A. K. TEWARI, K. D. SRIVASTAVA \& D.V. SINGH. 2004. Role of antibiosis in the biological control of spot blotch (Cochliobolus sativus) of wheat by Chaetomium globosum. Mycopathologia 157: 369-377.

AMES, L. M. 1963. A monograph of the Chaetomiaceae. Ser. 2: 1-125 Army Res Dev.., Washington DC.

ATSCHUL, S. F, W. GISH, W. MILLER, E.W. MYERS \& D. J. LIPMAN. 1990. Basic local alignment search tool. J. Mol. Biol. 215: 403-410.

ASGARI, B. \& R. ZARE. 2011. The genus Chaetomium in Iran, a phylogenetic study including six new species. Mycologia 103: 863-882.

BISWAS, S. K., K. D. SRIVASTAVA, R. AGGARWAL, P. DUREJA \& D. V. SINGH. 2000. Antagonism of Chaetomium globosum to Drechslera sorokiniana, the spot blotch pathogen of wheat. Indian Phytopath 53: 436-440.

BORNET, B. \& M. BRANCHARD. 2001. Nonanchored Inter Simple Sequence Repeat (ISSR) markers: reproducible and specific tools for genome fingerprinting. Plant Mol Biol Rep 19: 209-215. 


\section{P. Moya et al. - Chaetomium globosum as a potential biocontrol agent}

BREINHOLT, J., H. DEMUTH, M. HEIDE, G. W. JENSEN, M. MØLLER, R. I. NIELSEN, C. E. OLSEN \& C. N. ROSENDAHL. 1996. Prenisatin (5-(3-methyl-2-butenyl)-indole-2,3-dione): an antifungal isatin derivative from Chaetomium globosum. Acta Chem Scand 50: 443-445.

BREWER, D., J. M. DUNCAN, W. A. JERRAM, C. K. LEACH, S. SAFE S \& A. TAYLOR. 1972. Ovine illthrift in Nova Scotia 5. The production and toxicology of chaetomium, metabolites of Chaetomium spp. Can J Microbiol 18: 1129-1137.

BREWER, D., W. A. JERRAM, D. MEILER \& A. TAYLOR. 1970. The toxicity of cochliodinol, and antibiotic metabolite of Chaetomium spp. Can J Microbiol 16: 433-440.

BREWER, D. \& A. TAYLOR. 1978. The production of toxic metabolites by Chaetomium spp. isolated from soil of permanent pasture. Can J Microbiol 24: 10821086.

CARMONA, M. A. 2009. Enfermedades causadas por hongos necrotróficos. Manual de Identificación y manejo de las enfermedades del cultivo de la Cebada. 14-18.

CARMONA, M. A., D. E. BARRETO \& E. M. REIS. 1999. Detection, transmission and control of Drechslera teres in barley seed. Seed Sci Technol 27:761-769.

CHENNA, R., H. SUGAWARA, T. KOIKE, R. LOPEZ, T. J. GIBSON, D. G. HIGGINS \& J. D. THOMPSON. 2003. Multiple sequence alignment with the Clustal series of programs. Nucleic Acids Res 31:3497-3500.

CULLEN, D. \& J. H. ANDREWS. 1984. Evidence for the role of antibiosis in the antagonism of Chaetomium globosum to the apple scab pathogen, Venturia inaequalis. Can J Bot 62: 1819-1823.

CURTIS, M. D., J. GORE \& R. P. OLIVER. 1994. The phylogeny of the tomato leaf mold fungus Cladosporium fulvum syn. Fulvia fulva by analysis of rDNA sequences. Current Genet 25: 318-322.

DALBELLO, G. M., C. I. MÓNACO \& M. N. SISTERNA. 1994. Efecto de Trichoderma spp. sobre el control del tizón de la plántula en trigo ocasionada por Bipolaris sorokiniana. Fitopatol Bras 19: 394-400.

DI PIETRO, A., M. GUT-RELLA, J. P. PACHLATKE \& F. J. SCHWIN. 1992. Role of antibiotics by Chaetomium globosum in biological control of Pythium ultimum, a causal agent of damping off. Phytopathology 82: 131-135.

DOMSCH, K. H., W. GAMS \& T-H. ANDRESON. 2007. Compendium of soil fungi. vols 1 y 2. Academic Press, London.

DOYLE, J. J. \& J. L. DOYLE. 1990. Isolation of plant DNA from fresh tissue. Focus 12: 13-15.

DREYFUSS, M. 1976. Taxonomische Untersuchungen innerhalb der Gattung Chaetomium. Sydowia 28:50133.
ELLIS, M. B. 1971. Dematiaceous Hyphomycetes. Commonwealth Mycological Institute, Kew, Surrey.

ELLIS, M. B. 1976. More Dematiaceous Hyphomycetes. Commonwealth Mycological Institute, Kew, Surrey.

ENGSTROM, K., S. BRISHAMMAR, C. H. SVENSSON, M. BENGTSSON \& R. ANDERSSON. 1993. Anthraquinones from some Drechslera species and Bipolaris sorokiniana. Mycol. Res. 97: 381-384.

FERNANDEZ VALIELA, M. V. 1978. Introducción a la Fitopatología. Vol. III: Hongos. $3^{\mathrm{a}}$. Ed. Colección Científica del INTA. Buenos Aires.

GAO, K., X. LIU, Z. KANG \& K. MENDGEN. 2005. Mycoparasitism of Rhizoctonia solani by Endophytic Chaetomium spirale ND35: Ultrastructure and Cytochemistry of the Interaction. J Phytopathol 153: 280-290.

GOODWIN, S. B., L. D. DUNKLE \& V. L. ZISMANN. 2001. Phylogenetic analysis of Cercospora and Mycosphaerella based on the internal transcribed spacer region of ribosomal DNA. Phytopathology 91: 648- 658.

HUBBARD, J. P., G. E. HARMAN \& C. J. ECKENRODE. 1982. Interaction of a biological control agent Chaetomium globosum with seed coat mycoflora. Canadian J Microbiol 28: 431-437.

INFANTE, D., B. MARTÍNEZ, N. GONZALEZ \& Y. REYES. 2009. Mecanismos de acción de Trichoderma frente a hongos fitopatógenos. Rev. Protección Veg. 24: 14-21.

ISTIFADAH, N. \& P. A. MCGEE. 2006. Endophytic Chaetomium globosum reduces development of tan spot in wheat caused by Pyrenophora tritici-repentis. Australas Plant Path35: 411-418.

ISTIFADAH, N., J. SALEEBA \& P. MCGEE. 2006. Isolates of endophytic Chaetomium spp. inhibit the fungal pathogen Pyrenophora tritici-repentis in vitro. Can J Bot 84: 1148- 1155.

LEE, S. J. \& R. T. HANLIN. 1999. Phylogenetic relationships of Chaetomium and similar genera based on ribosomal DNA sequences. Mycologia 91: 434-442.

MANDAL, S, K. D. SRIVASTAVA, R. AGGARWAL \& D. V. SINGH. 1999. Mycoparasitic action of some fungi on spot blotch pathogen Drechslera sorokiniana of wheat. Indian Phytopath 52: 39-43

MAGyP. Manual de estimaciones agrícolas. Diciembre de 2014. Disponible en http://www.minagri.gob. ar/dimeagro/indicadores/ofer-dem-int/2014/01_ofer_ dem_int_jul2014.pdf. [Acceso: 12 de abril de 2015].

MANIATIS, T., E. FRITSCH \& J. SAMBROOK. 1982. Molecular Cloning. A Laboratory Manual. New York: Cold Spring Harbor Laboratory.

MOYA, P. \& M. N. SISTERNA. 2012. Estudios preliminares de Biocontrol de "Mancha en red" de la cebada en semilla, con cepas de Trichoderma spp. Ensayos "in vitro" Revista Sanidad de Semillas 2: 49-49. 
MOYA, P., C. CARRIÓN \& M. N. SISTERNA. 2015. Caracterización de pigmentos formados en la interacción fúngica Drechslera teres - Trichoderma spp. XXXV Jornadas Argentinas de Botánica, 23 al 26 de septiembre de 2015. Salta, Argentina.

NEERGAARD, P. 1979. Seed Pathology. vol. I and II. Revised Edition, Mac Millan Press, London.

NAKASHIMA, N., Z. MOROMIZATO \& N. MATSUYAMA. 1991. Chaetomium spp., antagonistic microorganisms phytopathogenic fungi. Journal of the Faculty of Agriculture, Kyushu University 36: 109-115.

RAYNER, R. W. 1970. A mycological color chart. Commonwealth Mycological Institute and British Mycological Society. Kew.

RODRÍGUEZ MOREJÓN, K. C. 2003. Estudio taxonómico (morfológico y molecular) de especies del género Chaetomium y géneros afines. Tesis doctoral. Facultad de Medicina y Ciencias de la Salud, Universidad Rovira y Virgili, Cataluña.

SETH, H. K. 1970. A monograph of the genus Chaetomium. Beih. Nova Hedwig 37:1-133.

SISTERNA, M. N. 2014. Mancha borrosa del trigo. En: Cordo, C. \& M. Sisterna (eds.), Enfermedades del trigo: avances científicos en la Argentina, pp. 173-186. Editorial de la Universidad de La Plata. La Plata.

SIVANESAN, A. 1987. Graminicolous species of Bipolaris, Curvularia, Drechslera, Exserohilum and their teleomorphs. Mycological Papers 158.1-261.

SÖRGEL, G. 1960. Zum Problem der Trennung von Arten bei Pilzen, dargestellt am Beispiel der Ascomycetengattung Chaetomium. Arch Mikrobiol 36:51-66.

SOYTONG, K. 1991. Antagonism of Chaetomium globosum to leaf spot disease of corn (Zea mays). Proceedings of the 29th Kasetsart University pp. 269-275. Plant Science, Kasetsart Univ., Bangkok (Thailand)- Bangkok.

SOYTONG, K. 1992. Biological Control of rice blast disease by seed coating with antagonistic fungi. Songklanakarin Journal of Science and Technology 14: 59-65.

SOYTONG, K., S. KANOKMEDHAKUL, V. KUKONGVIRIYAPA \& M. ISOBE. 2001. Application of Chaetomium species (Ketomium ${ }^{\circledR}$ ) as a new broad spectrum biological fungicide for plant disease control: A review article. Fungal Divers. 7: 1-15.

TAMURA, K., D. PETERSON, N. PETERSON, M. NEI \& S. KUMAR.2011. MEGA5: Molecular Evolutionary Genetics Analysis Using Maximum Likelihood, Evolutionary Distance, and Maximum Parsimony Methods. Mol. Biol. Evol. 28: 27312739.
TATHAN, S., P. SIBOUNNAVONG , K. SOYTONG \& C. TO-ANUN. 2012. Biological metabolites from Chaetomium spp. to inhibit Drechslera oryzae causing leaf spot of rice. Int J Agric Tech 8: 16911701.

THOMPSON, J. D., T. J. GIBSON, F. PLEWNIAK, F. JEANMOUGIN \& D. G. HIGGINS. 1997. The ClustalX windows interface: flexible strategies for multiple sequence alignment aided by quality analysis tools. Nucleic Acids. Res. 25: 4876-4882.

TVEIT, M. \& R. K. S. WOOD. 1955. The control of Fusarium blight in oat seedling with antagonistic species of Chaetomium. Ann Appl Biol 43: 538-552.

UNTEREINER, W. A., V. DÉBOIS \& F. A. NAVEAU. 2001. Molecular systematics of the ascomycete genus Farrowia (Chaetomiaceae). Can J Bot 79:321-333.

VANNACCI, G. \& G. E. HARMAN. 1987. Biocontrol of seed-borne Alternaria raphani and A. brassicicola. Can J Microbiol 33: 850-856.

VILA-AIUB, M. M., M. MARTÍNEZ-GHERSA \& C. GHERSA. 2003. Evolution of herbicide resistance in weeds: vertically transmitted fungal endophytes as genetic entities. Evol Ecol 17: 441-456.

VON ARX, J. A., J. GUARRO, M. J. FIGUERAS. 1986. The ascomycete genus Chaetomium. Beih Nova Hedwig 84:1-162.

WAKULIŃSKI, W., P. KACHLICKI, P. SOBICZEWSKI, M. SCHOLLENBERGER, C. Z. ZAMORSKI, B. LOTOCKA \& J. SAROVA. 2003. Catenarin production by isolates of Pyrenophora triticirepentis (Died.) Drechsler and its antimicrobial activity. J Phytopathol 151: 74-79.

WALLER, F., B. ACHATZ, H. BALTRUSCHAT, J. FODOR, K. BECKER, M. FISCHER, T. HEIER, R. HÜCKELHOVEN, C. NEUMANN, D. WETTSTEIN, P. FRANKEN \& K. KOGEL. 2005. The endophytic fungus Piriformospora indica reprograms barley to salt-stress tolerance, disease resistance, and higher yield. Proc. Natl. Acad. Sci. 102: 13386-13391.

WHITE, T. J., T. BRUNS, S. LEE \& J. TAYLOR. 1990. Amplification and direct sequencing of fungal ribosomal RNA genes for phylogenetics. In: Innis, M. A., Gelfand, D. H., Sninsky, J. J. \& T. J. White (eds.), PCR Protocols: A Guide to Methods and Applications, pp. 315-322. Academic Press, Inc., New York.

WIESE, M. V. 1987. Compendium of wheat diseases. American Phytopathological Society: St Paul.

Recibido el 16 de diciembre de 2015, aceptado el 19 de mayo de 2016. 